\title{
Social support for pregnant women
}

\begin{abstract}
This paper is a review of the literature concerning the importance of social support during pregnancy. Being pregnant is a special event in every woman's life, since it is associated with physical and mental changes. In addition to being a physiological event, pregnancy creates a burden for the body and induces stress. Pregnant women tend to suffer from fear of the unknown, especially regarding: baby, themselves, course of delivery, the need for a new role - of a mother, economic, professional, emotional situations and relationship with partner. The diagnosis of high-risk pregnancy and the need for hospitalization increase the incidence of negative emotions and experiences such as: permanent anxiety about the child's life, anger, sadness, doubts about the diagnosis, fear of pregnancy complications, frustration and dissatisfaction with the implementation of the functions of maternal concerns during the stay in the hospital. Anxiety and fear that appear during pregnancy affect the attitude of women in pregnancy and after childbirth.

Various authors frequently use the term "pregnancy-specific stress". There is a relationship between concerns, stress in the mother during pregnancy and lifestyle, duration of pregnancy, and the possible complications during intrauterine and neonatal life. Social support significantly influences the quality of coping with stress in pregnant women. If a pregnant woman receives strong social support from her network, the negative emotions and concerns would be reduced. Receiving support also boosts the chances of successful pregnancy completion. The people from the immediate social network of a pregnant woman, like their partner, spouse, family, friends, midwife, doctor, are the most vital source of support.
\end{abstract}

Keywords: pregnancy, specific stress, social support.

DOI: $10.1515 /$ pjph-2015-0048

\section{INTRODUCTION}

The woman's body during pregnancy experiences some anatomical and psychological changes [1]. In this state, a woman's emotional state varies from the joy of waiting for the birth of a child after the occurrence of fears related to the course of pregnancy, childbirth, and concerns about the state of their own health and the health of the child [2-4]. Pregnancy determines the changes in lifestyle and patterns of everyday functioning of women [5]. According to the concept of procreative psychology, the first stage of pregnancy comes to an end with the first appearance of fetal movements, i.e. at about $20^{\text {th }}$ week in primigravida and in multiparous women between the $16^{\text {th }}$ and $18^{\text {th }}$ week of gestation. The next stage of pregnancy lasts until the fear of the impending birth starts to appear, and the last stage covers the period to the birth of the child [6].

During the first trimester, which is the timeframe between the moment of conception and the $12^{\text {th }}-13^{\text {th }}$ week of pregnancy, the following symptoms may appear: vomiting, nausea, lack of appetite or excessive appetite, frequent urina- tion, breast tenderness, and sleepiness [7]. According to evolutionary psychology experts, these problems are a reaction of the mother and child to the harmful factors for a healthy pregnancy. This is the time when women experience a whole variety of feelings, both joy and euphoria and fear, anxiety, tears and fear of pregnancy loss [8]. During the second trimester of pregnancy, which is between the $14^{\text {th }}$ week to the end of the $26^{\text {th }}$ week, women rarely feel any discomfort. It is a time when both hormonal and emotional stability appears, with some negative emotions, like constipation, salivation or pain in the spine. During that stage of pregnancy, the woman's appearance changes and the maternal instinct appears, along with strengthened fetal movements that help the pregnant to imagine the unborn baby. This is the time when parental awareness and perceiving the child as a separate entity start to appear $[7,9]$.

The third trimester of pregnancy, which means the period between the $27^{\text {th }}$ week of gestation and birth, is characterized by a concentration of attention on the impending birth. The thoughts about giving birth tend to cause anxiety, uncertainty or even fear, the concern is usually about the course

\footnotetext{
${ }^{1}$ Independent Unit of Midwifery Skills, Medical University of Lublin, Poland

${ }^{2}$ Chair and Department of Endocrine Gynecology, Medical University of Lublin, Poland

${ }^{3}$ Midwifery Department, Gynecology and Nursing, Midwifery Department, Medical University of Lublin, Poland
} 
of delivery and the possible injuries caused by childbirth, the baby's health, and changes in the partnership [10]. The pregnant woman is exposed to a variety of illnesses, like hemorrhoids, backache, stretch marks on the skin, sleep disorders, urinary frequency, heartburn, and fatigue, all as a result of the fetus's gaining weight. Many women complain about mental slowing, impaired memory processes, concentration problems, problems with rapid decision-making, and aversion to mental effort and troubleshooting [7,11].

There are some individual differences when it comes to psychological and biological acceptance of pregnancy in women. Such factors as one's age, situation at home and social position, future plans, reproductive experience and socio-emotional maturity affect it [12]. Even planned and longed-for pregnancies can induce some stressful situations. Both Glynn et al. [13] and Kuryś [14] ascribe it to the fact that pregnancy is a critical emotional event which is so different from the daily life that it completely changes the female's functioning, both in the family and society. The psychological life events can affect the normal course of pregnancy in humans Pregnancy is a turning point in life both for pregnant women and their partners. It can sometimes cause problems, particularly if this is the first pregnancy or an unplanned event. Any changes occurring during pregnancy can appear as stressful, particularly when accompanied by emotions such as anxiety, fear or uncertainty [15]. Ilske, Przybyła-Basista [16] pointed to the most common emotions appearing in pregnancy: fear of the unknown, concerns about the child and own self, and the course of childbirth affect the course of pregnancy and attitude to different situation. In addition, they arouse concern: the need to take a new role of a mother, concerns about the economic situation, professional, emotional, and lack of social support from loved ones.

High-risk pregnancies usually create a need for hospitalization. Also, the limitation of basic daily activities constitute an additional source of stress and induce many negative emotions that women with normal pregnancy never experience. For instance, there is a permanent anxiety about the child's life, anger, sadness, thoughts and doubts about the diagnosis, fear of further complications during pregnancy, frustration and dissatisfaction with the implementation of the functions of maternal concerns on hospitals, separation from family, communication difficulties with medical staff, lack of support from family or group therapy $[6,17,18]$. On the other hand, Sockol et al. [19] and Semczuk et al. [20] suggested that high-risk pregnancy can induce additional psychological stress. Various authors often point to the socalled "pregnancy-specific stress" and the discussion about the effect of stressors on pregnancy and the child's condition continues. The research conducted by Lobel et al. [21] Evans et al. [22], Muglia et al. [23] Wadhava et al. [24] and Voellmin et al. [25] show that there is a correlation between fears and stress, lifestyle, duration of pregnancy and complications of neonatal period.

The stress felt by mothers could lead to a reduction of the placental disturbance of the blood flow and the fetus's well-being [26-28]. There are numerous reports pointing to an excessive role that stress plays during abnormal pregnancies. The stress felt by the mother can lead to a miscarriage, premature birth, low birth weight, and impaired development of the nervous system of the fetus. During the $10^{\text {th }}$ week of pregnancy, the molding process of fetal nerve cells (neurogenesis) begins, while between $24^{\text {th }}$ and $30^{\text {th }}$ week of pregnancy, some neural connections between neurons (synaptogenesis) are being created. The stress experienced by pregnant women may contribute to an abnormal development of the nervous system in the fetus, causing some disturbances in the development of cognitive skills of the child, such as perception, storage and processing of information [22-25,29]. Some long-term consequences of pregnancy stress include: child's emotional problems, hyperactivity disorder, attention deficit, behavioral and learning difficulties [30-32].

Some measures minimizing the consequences of pregnancy stress should be undertaken by the therapeutic care team. The typology of Endler and Parker can be useful for dealing with stress. These two authors define the style of coping with stress as a behavior characteristic for a person dealing with different stressful situations. Remedial actions to be taken when stress is a consequence of the interaction that occurs between the event and the style of coping with stress [33,34]. Endler and Parker believe that the style focused on the task determines how to cope with taking specific challenges in a bid to resolve the issue. The style focused on emotions consists of actions aimed at reducing the emotional tension by focusing on their own person, their own emotional experiences such as: tension, anger, guilt in stressful situations. In contrast, the avoidance style means avoiding thinking about the problem or trying to avoid difficult situations. Somnolence, thinking about pleasant things, reading books, overeating or seeking social contacts excessively, can be counted among activities that let the pregnant woman avoid the need to resolve a stressful situation [34-36].

The most constructive and desirable way of coping with stressful situations during pregnancy would be a style focused on solving the problem. The task of utmost importance for a pregnant woman is to give birth to a healthy baby and assuming the role of a mother [37,38]. Flexibility, being open to changes and having a positive self-esteem, the ability to plan and pursue life goals, solve problems, are a resource for an effective coping with stress during pregnancy $[34,37,39]$. Social support is the main factor influencing the quality of coping with stressful situations [40]. This is a kind of interaction that one or more individuals engage in, as a way of coping with difficult, problematic and stressful situations. It might be emotional, informational or instrumental. Social support in popular opinion constitutes aid and the proximity of other people and it has a positive effect over well-being and health. The aim of help is the reduction of stress through the exchange of different information [40]. Social exchange is the process leading to establishing long-lasting social relationships between, at least, two people [41].

Pregnant woman should look for creating long-lasting relationships with family members and loved ones, as well as the midwife or physician who provide medical care $[6,42]$. Social support can take one of the following forms: emotional, informational, instrumental, subjective validation. Emotional support is the transfer of positive emotions and showing concern for the person supported. Information 
support is an exchange in the interaction that contributes to the proper understanding of the situation. This support is to share experiences by people experiencing similar concerns or difficulties. Instrumental support is the transfer of information relating to certain procedures in a given situation. This kind of support provides material assistance and physical activity for the people in need. Support of validation evaluative, character is indicating that the individual has the ability to perform activities resulting from carrying out of a social role. It is based on displaying the recognition, admiration and acceptance, which has a positive effect on increasing the self-supported person [40].

Many pregnant women need emotional, informational and material support which would let them assume the role of a mother [42]. Social support, which is obtained by a pregnant woman helps reduce feelings of stress or sense of concern $[40,42]$. The most important sources of social support for pregnant women include the people from their immediate surroundings. Natural sources of support, such as the partner, spouse, family, friends, social groups, which support relationships are functioning spontaneously, are reciprocal [9]. It was reported that one partner is the fundamental and natural source of social support, favorably influencing the emotional state of a pregnant, scope of use of prenatal care, which in turn contributes to the orderly termination of pregnancy $[6,43,44]$. Emotional support is manifested by: caring, understanding and empathy and generating positive feelings in the supported person. It helps create a sense of understanding, care, hope in response to expressed concerns of the supported person, in form of anxiety, fear and the emerging states of mental tension [42].

Pregnant women receiving appropriate support from relatives, medical personnel and the environment can better accept changes related to pregnancy. Also, they take measures to encourage the orderly development of the pregnancy and accept a new role in life - becoming a mother. Furthermore, the incidence rate of postpartum depression rates are much lower in this group of women [45]. During recent years, numerous reports concerning the importance of social support in stressful situations and illness have started to appear.

Broadening the scope of knowledge about fear, anxiety or stress in pregnant women and the need for social support can significantly contribute to optimising the psychoprophylactic action during pregnancy as well as to a healthy pregnancy.

\section{REFERENCES}

1. Kempiak J. Zmiany ustrojowe w przebiegu ciąży. In: G. H. Bręborowicz (ed). Położnictwo i Ginekologia tom I. Warszawa: Wydawnictwo Lekarskie PZWL; 2007. p. 41-52.

2. Byrd-Craven J, Massey AR. Lean on me: Effects of social support on low socioeconomic - status pregnant women. Nurs Health Sci. 2013;15:374-78.

3. Parcells DA. Women's mental health nursing: depression, anxiety and stress during pregnancy. J Psychiatr Ment Hlt. 2010;17:813-20.

4. Chrzan-Dętkoś M. Psychodynamiczne rozumienie macierzyństwa implikacje dla pracy klinicznej. Psychoter. 2010;1(152):5-14.

5. Machaj-Szczerek A, Stankowska I. Przekonania dotyczące macierzyństwa - badania własne. Pielęg Pol. 2013;3(49):176-86.
6. Bielawska-Batorowicz E. Psychologiczne aspekty prokreacji. Katowice: Wydawnictwo Naukowe „Śląsk”; 2006. p. 111-51.

7. Bień AM, Grudzińska M. Przebieg ciąży fizjologicznej. In: A. M. Bień (ed). Opieka nad kobieta ciężarną. Warszawa: Wydawnictwo Lekarskie PZWL; 2009. p. 45-54.

8. Libera A. Problemy psychologiczne okresu ciąży. In: M. MakaraStudzińska, G. Iwanowicz-Palus (ed). Psychologia w położnictwie i ginekologii. Warszawa: Wydawnictwo lekarskie PZWL; 2009. p. 15497.

9. Heszen I, Sęk H. Psychologia zdrowia. Warszawa: Wydawnictwo Naukowe PWN; 2009. p. 309-17.

10. Gebuza G, Kaźmierczak M, Gierszewska M, et al. Lęk przed porodem w III trymestrze ciąży i jego powiązania ze stanem noworodka. Med Ogólna Nauk Zdr. 2015;21(1):39-44.

11. Fraś M, Gniadek A, Poznańska-Skrzypiec J, Kadłubowska M. Styl życia kobiet w ciąży. Hygeia Pub Health. 2012;47(4):412-7.

12. Makara-Studzińska M, Morylowska-Topolska J, Sygit K, et al. Sociodemografiphical and psychosocial determinants of anxiety symptoms in a population of pregnant women in the regions of central and eastern Poland. Ann Agric Environ Med. 2013;20(1):195-202.

13. Glynn LM, Schetter CD, Hobel CJ, Sandman CA. Pattern of perceived stress and anxiety in pregnancy predicts preterm birth. APA. 2008;27:43-51.

14. Kuryś K. Urodzenie pierwszego dziecka jako wydarzenie krytyczne w życiu kobiet i mężczyzn. Kraków: Oficyna Wydawnicza Impuls; 2010. p. 65-83.

15. Wojaczek M. Kształtowanie się zmian i percepcja poczętego dziecka w poszczególnych etapach ciąży. Piel Zdr Publ. 2012;2(1):73-7.

16. Ilska M, Przybyła-Basista H. Measurement of women's prenatal attitudes towards maternity and pregnancy and analysis of their predictors. Health Psychology Report. 2014;2(3):176-88.

17. Bączek G, Cebulska V, Koźlak V, et al. Poziom lęku przedporodowego w czasie ciąży. Probl Hig Epidemiol. 2011;92(4):774-7.

18. Tałataj A, Fischer B, Kupcewicz E. Potrzeby i oczekiwania hospitalizowanych ciężarnych z patologii ciąży. Probl Piel. 2012;20(2):228-32.

19. Semczuk M, Steuden S, Szymona K. Ocena nasilenia i struktury stresu u rodziców w przypadkach ciąży wysokiego ryzyka. Ginekol Pol. 2004;75(6):417-24.

20. Sockol LE, Epperson CN, Barber JP. The relationship between maternal attitudes and symptoms of depression and anxiety among pregnant and postpartum first-time mothers. Arch Women Ment Hlth. 2014;17(3):199-212.

21. Lobel M, Cannella DL, Graham JE, et al. Pregnancy-Specific Stress, Prenatal Health Behaviors, and Birth Outcomes. Health Psychol. 2008;27(5):604-15.

22. Evans J, Heron J, Patel RR, Wiles N. Depressive symptoms during pregnancy and low birth weight at term: longitudinal study. Br J Psychiatry. 2007;191:84-5.

23. Muglia LJ, Katz M. The enigma of spontaneous preterm birth. N Engl J Med. 2010;362:529-35.

24. Wadhwa PD, Entringer S, Buss C, Lu MC. The contribution of maternal stress to preterm birth: issues and considerations. Clin Perinatol. 2011;38:351-84.

25. Voellmin A, Entringer S, Moog N, et al. Maternal positive affect over the course of pregnancy is associated with the length of gestation and reduced risk of preterm delivery. J Psychosome Res. 2013;75(4):336-40.

26. Muller-Nix C, Forcade-Guex M, Pierrehumbert B, et al. Prematurity, maternal stress and mother - child interactions. Early Hum Dev. 2004; $9(2): 145-58$.

27. Van den Berg Bea RH, Mulder EJH, Mennes M, Glover V. Antenatal maternal anxiety and stress and neurobehavioral development of the fetus and child links and possible mechanisms. Neurosci Biobehav R. 2005;29:237-58.

28. Sarkar P, Bergman K, O Connor T, Glover V. Maternal antenatal anxiety and amniotic fluid cortisol and testosterone possible implications for foetal programming. J Neuroendocrinol. 2008;20:489-96.

29. Beydoun H, Saftlas AF. Physical and mental health outcomes of prenatal maternal stress in human and animal studies: a review of recent evidence. Paediatr Perinat Ep. 2008;22:438-66.

30. Talge N, Neal C, Glover V. Antenatal maternal stress and long - term effects on child neurodevelopment: how and why? J Child Psychol Psychiatry. 2007;48(3-4):245-61.

31. DiPietro J, Novak M, Costigan K, et al. Maternal psychological distress during pregnancy in relation to child development at age two. Child Dev. 2006;77:573-87. 
32. Rodriguez A, Bohlin B. Are maternal smoking and stress during pregnancy related to ADHD symptoms in children. J Child Psychol Psyc. 2005;46(3):246-54.

33. Strelau J, Jaworska A, Wrześniewski K. Kwestionariusz radzenie sobie w sytuacjach stresowych CISS. Warszawa: Pracownia Testów Psychologicznych PTP; 2005.

34. Mariańczyk K, Libera A, Oleszczuk J. Poczucie beznadziejności a style radzenia sobie ze stresem u kobiet po porodzie przedwczesnym. Ginekol Pol. 2010;81:342-6.

35. Wrześniewski K. Style a strategie radzenia sobie ze stresem. In: I. Heszen-Niejodek, Z. Ratajczak (ed). Człowiek w sytuacji stresu. Problemy teoretyczne i metodologiczne. Katowice: Wydawnictwo Uniwersytetu Ślaskiego; 1996. p. 44-64.

36. Żuralska R, Postożny D, Sein Anand J. Kobiety w ciąży, a strategie radzenia sobie ze stresem i style przywiązania. Prz Lek. 2013;70(8):5614.

37. Podolska MZ, Majkowicz M, Sipak-Szmigiel O, Ronin-Walknowska E. Style radzenia sobie w sytuacjach stresowych a Lęk - stan i Lęk - cecha u kobiet z objawami depresji okołoporodowej. Ginekol Pol. 2009;80:201-6.

38. Heszen I. Od czego zależy zachowanie wobec stresu? Właściwości podmiotu, jako wyznaczniki procesu radzenia sobie. In: I. Heszen. Psychologia stresu. Warszawa: Wydawnictwo Naukowe PWN; 2014. p. 95-136.

39. Rutkowska A, Rolińska A, Kwaśniewski W, et al. Style radzenia sobie ze stresem u kobiet w ciąży prawidłowej i wysokiego ryzyka. Curr Prob Psychiatry. 2010;11(4):328-33.

40. Sęk H. Rola wsparcia społecznego w sytuacjach stresu życiowego. O dopasowaniu wsparcia do wydarzeń stresowych. In: H. Sęk, R. Cieślak (ed). Wsparcie społeczne, stres i zdrowie. Warszawa: Wydawnictwo Naukowe PWN; 2006. p. 18-9, 49-67.

41. Blau P. Wymiana społeczna. In: P. Sztompka, M. Kuci (ed). Socjologia. Kraków: Znak; 2005. p. 103-11.

42. Koss J, Rudnik A, Bidzan M. Doświadczanie stresu a uzyskiwane wsparcie społeczne przez kobiety w ciąży wysokiego ryzyka. Doniesienia wstępne. Family Forum. Probl Współcz Rodz. 2014;4:183-202.

43. Kornas-Biela D. Wokół początku życia ludzkiego. Warszawa: Instytut Wydawniczy Pax; 2004

44. Bielenik Ł, Bidzan M, Salwach D, Zdolska-Wawrzkiewicz A. Wsparcie od partnera a radzenie sobie z problemami prokreacyjnymi. In: L. Golińska, E. Bielawska-Batorowicz (ed). Rodzina i praca w warunkach kryzysu. Łódź: Wydawnictwo Uniwersytet Łódzki; 2011. p. 177-86.

45. Bielawska-Batorowicz E. Psychologia prokreacyjna - stan obecny i perspektywy. Acta Universitatis Lodziensis. Folia Psychologica. 2002;6:15-28.

\section{Corresponding author}

Agnieszka Skurzak

Independent Unit of Midwifery Skills, Medical University of Lublin, Poland tel. 609-209-506

E-mail: agnieszka.skurzak@umlub.pl 